\title{
Perception of Secondary School Teachers for the Importance of Implementing the Ivan Illich's Deschooling Principles in the Educational Learning Process in Jordan
}

\author{
Mohammad Saleem Al-Zboon ${ }^{1}$, Lina Majed Al-Maalouf ${ }^{2}$, Ghunaim Humoud AlTashah ${ }^{3}$ \& Abdel Salam Fahad \\ Al Awamrah ${ }^{4}$ \\ ${ }^{1}$ Faculty of Educational Sciences, University of Jordan, Jordan \\ ${ }^{2} \mathrm{PhD}$ Student, Foundations of Education, University of Jordan, Jordan \\ ${ }^{3} \mathrm{PhD}$ in Educational Administration, state of Kuwait, Kuwait \\ ${ }^{4}$ Faculty of Educational Sciences, University of Jordan, Jordan \\ Correspondence: Prof. Mohammad Saleem Al-Zboon, Faculty of Educational Sciences, University of Jordan, \\ Jordan. E-mail: zboon75@yahoo.com
}

Received: February 1, 2018

Accepted: March 6, 2018

Online Published: March 28, 2018

doi:10.5539/mas.v12n4p98

URL: https://doi.org/10.5539/mas.v12n4p98

\begin{abstract}
This study aimed at exploring the perception of secondary school teachers for the importance of implementing the Ivan Illich's Deschooling principles in the educational learning process in Jordan. For that the researchers adopted the descriptive analysis methodology through the use of the questionnaire as a study tool on a sample of (100) secondary school teachers in the three regions of Jordan (Middle Region, North Region and South Region). The study concluded that there is no significant difference between the levels of educational qualification and gender at the level of $(\alpha=0.05)$ in the degree of secondary school teachers' perception of the importance of applying the Deschooling principles of Ivan Illich in the educational learning process. And the researchers recommended that to re-examine the objectives of education in the light of a renewed vision for sustainable human and social development that is equitable and can be applied together, and in this vision we should take into account the social, environmental and economic dimensions of the comprehensive development processes and linking them to education processes.
\end{abstract}

Keywords: Ivan Illich's Deschooling principles, secondary school teachers

\section{Introduction}

Education is considered a subsystem social system within an integrated system; namely the social system, and the education portal is one of the most important engines within the system that achieve the progress of countries. Therefore, countries have sought to put education in the priority of their development programs, especially with the advancement of the means of communication and technological revolution as the traditional systems are insufficient to meet the requirements of the individuals and society (Shaidullina, Pavlova, Minsabirova, Burdukovskaya, Yunusova, Letyaev \& Afanasev, 2015).

Education has an active role in the development process in all its dimensions, as it means human development and the development of competencies and self-capacity, providing the elements of creativity, innovation and productivity of high quality. This requires the development of individual skills and abilities in the preparation of a new generation that can deal with the outputs within the overall total quality standards (Bauto, 2016).

As a result of the fact that any exit is the entrance to another process with a wider circle, it was necessary to pay attention to the main outputs, which are essential aspects in the structure of the community and the economic development. The students are the outputs of the schools and the inputs of the universities, which will feed the labor market, and the inputs of the economy and national income (Mustafa, 2016).

Modern life is witnessing developments, and deep and multiple changes in knowledge and technology that requires building a person who is capable of self-learning through the provision of intellectual skills and technology, which requires that educational institutions to respond to these changes and interaction, and play their role to the fullest in order to form and prepare a generation looking for knowledge and science, with a 
creative mind, and believes in dialogue and freedom. The future education is based on self-education that is concerned with the personality of the learner and his interests, and the opportunity for him to practice active and effective learning, which will develop his talent; and also stimulates motivation for learning, interaction, and increases mutual communication between teachers and learners (AlZboun \& ababneh, 2010).

The revolution of communication and technology has reduced and demarcated the geographical boundaries and reduced the distances, it has enabled individuals to easily access, assemble and store information, it has also led to the mixing of ideas and cultures in the human community, creating wide cultural changes that have helped to create new trends and to the disappearance of other tendencies (Al-Sheikh, 2007).

In the light of these developments, the orientation of the Deschooling, sponsored by Ivan Illich, has emerged. He called for the secularization of education, teaching and learning to become an exploratory creative process that is concerned with the personal development of the students. He stressed that the school has become a tool of adaptation that deprives man of all his weapons, The human society includes a number of institutions, whether educational, medical, media, etc. These institutions work to monopolize the service or job they claim to be confused with their value and the function they perform. Illich 's idea was that the path to social reform is through the dismantling of these institutions (Nasser \& Al-Zboun, 2015).

This trend is a contemporary social educational philosophy aimed at dismantling the service-based society institutions based on the transformation of value into a commodity, and aspires to liberalize the philosophy and spirit of the domesticated society by these institutions (Illich, 1971).

Where the supporters of the Deschooling demands the abolition of the educational system and the creation of a society without a school; this trend was supported by several pioneers who supported and developed this idea, among them Moore and Paulo Freire. The most prominent of these was the Brazilian philosopher Illich. The idea of Deschooling is about the impact of the natural environment on the individual's life on education: family, religious, recreational institutions and social media; and thus the individual is out of school idea and its supervision and guidance (Todd, 2012).

The school is not just every educational institution established by society, but all its institutions, so that the whole society is the great school for all. The school, according to Illich, has become a tool of adaptation that necessarily leads to material poverty, psychological infertility and social polarization. Illich described the system of education in schools from curricula, examinations, certificates and the compulsory system of attendance and absence as the closest to imprisonment (Reimer, 1971).

Therefore, the path to reform is to dismantle these institutions. In the opinion of Illich, the society is full of unutilized competencies and institutions that educate, such as the media, clubs and many others, so the essence of Deschooling is that it is a process of cultural transformation that restores the freedom of expression and freedom of information (Nasser \& Al-Zboun, 2015).

\section{Literature Review and Previous Studies}

After elucidating the ideas and extensive research by Illich, he reached a new system that illustrates the alternatives of education, namely the educational materials network, which is an educational network that provides services to the students so that the natural environment becomes accessible to them rather than being restricted to certain groups. Students can meet their peers at the same level of science and interest, share ideas and information, and professional educators. Illich sees the benefit of qualified teachers so that they are divided into three categories: The first category controls the management of these networks; the second category provides guidance services for students and the third category provides educational services and exchange information between students and educators. And the fourth alternative is the network of exchange of experts through which the opportunity is available to those who have certain skills wishes to provide and benefit from it, whether parents or anyone who has these skills by setting up centers in villages (Nasser \& Al-Zboun, 2015).

Several studies have addressed some of the sub-issues related to Deschooling ideas. The study of AlZboun \& Ababneh (2010) aimed to analyze the elements of the educational system related to the teacher and the student, the teaching process, the curriculum, the educational leadership in the light of information and communication technology, and the presentation of a future vision of the electronic confidence skills that the students show in the educational process according to this technology. The theoretical and analytical approach to the future was adopted by the researchers, and the study has concluded that the teacher will change his role to become a guide and facilitator for the students, and must have a range of competencies and new skills to be an active participant and a creative producer of knowledge and participation, and also capable of interacting with society and with the changing world. Therefore, he must possess new competencies previously unknown in relation to the use of new 
techniques to acquire, process and share knowledge with others. The teaching process will become more interesting and effective by using ICTs, where the teacher prepares the appropriate environment for learning, and students begin learning using computers with different software, learning resources, data collection, evaluation and interpretation, online search, communication, interaction and collaboration with classmates and students from different regions and countries, and will lead to the emergence of the so-called blended learning.

Abu Fakhr (2012) studied the aim of identifying the effect of virtual learning in the collection of the teaching methods of sociology among the students of the Diploma of Educational Qualification at the Syrian Virtual University. The sample of the study consisted of (30) experimental students of the diploma of educational qualification in sociology at the Faculty of Education, University of Damascus, and (30) students who were taught in traditional classes and using traditional methods. The results indicated that the effectiveness of virtual learning in the achievement of students of the diploma of educational qualification in the Syrian Virtual University, compared to the achievement of the students of the diploma of educational qualification in the Faculty of Education at Damascus University has appeared by the difference of statistical significance at the level of (0.01) (Male and female) and the achievement of the control group (male and female) students in favor of the experimental group using virtual learning. The results also showed a statistically significant difference at the level of (0.01) between the pre and post-application of the achievement test in the experimental group, for the benefit of the post-application.

Clara and Barbera (2014) study aimed at analyzing the Connectivism, which has been argued to be a new learning theory, has emerged in the field of online learning during the last decade. On the World Wide Web at least, connectivism promises to establish learning spaces similar to those that Ivan Illich imagined in 'Deschooling Society', through so-called massive online open courses (MOOCs). In this paper, we critically examine the theoretical postulates of connectivism and identify three important psychological and epistemological problems, namely the lack of a solution to the learning paradox, the under conceptualization of interaction and the inability to explain concept development. Some of the theoretical deficiencies in question may explain certain learning problems experienced by participants in MOOCs. The paper concludes that, although MOOCs are a worthwhile experience and ought to be continued, connectivism as a learning theory has significant theoretical problems and should be profoundly revised if it is to explain and foster learning in such environments.

Al-Thubayani (2015) also conducted a study aimed at trying to explore the future of Deschooling in the Saudi society in the field of cognitive, psychological, social, and skills. The sample of the study consisted of (28) experts specialized in the fields of pedagogy, psychology and sociology within and outside the Kingdom of Saudi Arabia, 28) to explore the future of schooling in the Saudi society. The study adopted the analytical descriptive methodology and the use of the Delphi method to deal with complex problems. The study concluded that the school is no longer the only source of knowledge and awareness. The future is full of educational alternatives that can be competitive. Including Deschooling education. Many of the non-pedagogic modes of education are lacking the organizing and managing, ideas and information retrieval; because they require a combination of exercises and advance planning.

Vijaya \& Ravi (2015) study aims to assess the Deschooling abilities in primary school children If a co-educational school in Andhra Pradesh. Students of class I to IV were selected by simple random sampling method. A questionnaire pertaining to each student and containing parameters of non-scholastic abilities was given to the class teacher for assessment. The anthropometric measurement of each student were also taken. Secondary data relating to student scholastic performance, family details like income and occupation were collected from student records maintained in the school. About 35(44,8\%)of the students showed highest non-scholastic score of 55-60.Females showed a higher score compared to males which was statistically significant. Nutritional status was not seen to have any association with non- scholastic and scholastic abilities of the students. There was a significant association between occupation of the parents of students and Deschooling abilities of the student. Non scholastic abilities are not learned by rote as done with scholastic abilities. There have to be fostered and the onus rest with the parents and the teachers.

The previous studies have dealt with the subject of Deschooling in many aspects and did not address Deschooling education process directly, while the current study examines the perception of secondary school teachers of the applicability of the principles of Deschooling according to Ivan Illich in the educational learning process.

\section{Problem Statement}

The school is no longer the only factor that earns the student education, knowledge and information, but the 
individual has the freedom to choose the method of education and the one that provides him with information, knowledge and facts in the light of many of the variables in the world through research and identification of modern teaching methods, which leads individuals to learn through Deschooling education, which has a lot of knowledge and information on which the individual builds his education and his ideas, which in turn qualify him to face the society in various cultures and orientations through the scientific aspect, and thus the problem of study is determined on the level of secondary school teachers' perception of the importance of implementing the Deschooling principles of Ivan Illich in the educational process, hence the following study questions have emerged:

\subsection{Question One}

What is the degree of perception of secondary school teachers in Jordan for the importance of implementing Deschooling principles of Ivan Illich in the educational learning process?

\subsection{Question Two}

Are there statistically significant differences at the level of $(\alpha=0.05)$ in the study sample to the importance of applying the Deschooling principles of Ivan Illich in the educational learning process according to gender and scientific qualification variables?

\section{Study Aim and Importance}

The study aims to identify the perception of secondary school teachers to the importance of applying the Deschooling principles of Ivan Illich in the educational learning process and its relationship to some variables.

The importance of the study is that it deals with the perception of secondary school teachers and the importance of applying the Deschooling principles of Ivan Illich in the educational learning process, highlighting the Deschooling education in the 21st century in the light of the information and technology revolution and the multiplicity of educational modes, ways of education, society, and exercise their skills within their communities. The importance of the study also stems from the importance of Deschooling in the reality that the student is living and needs in the light of many needs that lead the learner to use many media as social networking sites due to the strength of its impact on individuals and the delivery of ideas to the recipients, as well as the use of the Internet in learning and openness to the outside world and receiving many useful information that is established in the minds of individuals through the Audiovisual Media.

\section{Terminology}

Educational Learning Process: It is a set of activities and processes that take place inside and outside classrooms, in order to provide students with practical, scientific and positive skills, and develop a comprehensive and balanced development of students (Putnam \& Borko, 2000).

Deschooling: Is a form of education in which learning depends on the learner's interests, tendencies, desires and goals, also referred to as innate learning, exploratory learning, self-learning or self-directed learning, and is carried out outside formal education through family, religious and recreational institutions, professional associations, and social media (Nasser \& AlZboun, 2015).

And procedurally Deschooling is defined as a series of educational influences on the individual in the natural environment within his tendencies and interests, and affect the behavior, ideas, actions and gaining many skills that will increase the experience of the learner and raise his scientific and cognitive level.

\section{Study Limitations}

The study limitations are defined by the following limits:

Objective limitations: Identifying the perception of secondary school teachers in Jordan to the importance of implementing the Deschooling principles of Ivan Illich in the educational learning process

Time limitations: The study was implemented in the academic year (2017-2018).

Geographic limitations: This study was limited to three regions in the Hashemite Kingdom of Jordan, namely the Central Region, the Northern Region and the Southern Region.

Human Limitations: The study was limited to a sample of all secondary school teachers in the public schools for the academic year (2017-2018) from the three regions.

\section{Study Producers}

\subsection{Study Population}

The study population consists of all secondary school teachers in Jordan 


\subsection{Study Sample}

The sample of the study was selected randomly, and consisted of (100) teachers from secondary school in Jordan. The characteristics of the study sample are shown in table (1).

Table 1. Characteristics of the study sample

\begin{tabular}{|c|c|c|c|}
\hline \multicolumn{2}{|c|}{ Variable } & Frequency & Percentage \\
\hline \multirow{2}{*}{ Gender } & Male & 48 & $48.0 \%$ \\
\hline & Female & 52 & $52.0 \%$ \\
\hline \multicolumn{2}{|l|}{ Total } & 100 & $100 \%$ \\
\hline \multirow{3}{*}{ Qualification } & BA & 74 & $74.0 \%$ \\
\hline & M.A. & 13 & $13.0 \%$ \\
\hline & Ph. D. & 9 & $9.0 \%$ \\
\hline \multicolumn{2}{|l|}{ Total } & 100 & $100 \%$ \\
\hline
\end{tabular}

\subsection{Study Tool}

The researchers prepared the study tool (questionnaire) after reviewing the literature and the previous studies related to the subject. The questionnaire included two parts: the first part included the Personal data. The second part consists of (59) paragraphs, and was designed on the basis of the five-dimensional Likert Scale.

\subsubsection{Questionnaire Validity}

Ensuring the face Validity of the measurement tool was the aim; the questionnaire was reviewed by a number of faculty members of the Jordanian universities in the same field of the research, for identifying the suitability of the questionnaire for the goals to be achieved, and by retrieving all suggestions, all the necessary adjustments on the paragraphs of the questionnaires was made, by deleting, adding some paragraphs, and by rephrasing others.

\subsubsection{Questionnaire Reliability}

For ensuring the Reliability of the questionnaire, the researcher used the internal consistency coefficient $(\alpha)$ according to the alpha Cronbach equation, and the value of $(\alpha) 95 \%$, which is very high when compared with the minimum acceptable of $60 \%$.

And to interpret the results of the study, the researchers used the following arithmetic means:

- Less than 2.5 application degree is low

- 2.5-3.5 application degree is medium

- $\quad$ Larger than 3.5 application degree is high

\section{Study Results and Discussion}

\subsection{Results of the First Question}

In order to answer questions of the study, the arithmetic means and the standard deviations of each of the paragraphs of the tool were extracted, and table (2) shows these results.

Table 2. Arithmetic means, standard deviations and ranking of the importance of applying the Deschooling principles of Ivan Illich in the educational learning process in a descending order

\begin{tabular}{clcccc}
\hline No. & \multicolumn{1}{c}{ Field } & Arithmetic means & Standard deviations & Rank & Level \\
\hline 2 & Exchange of experts & 4,35 & 0.81 & 1 & High \\
4 & Professional Educators & 4,13 & 0.67 & 2 & High \\
1 & Network educational materials & 4,08 & 0.71 & 3 & High \\
3 & Peer compatibility & 4,08 & 0.65 & 3 & High \\
& Total score & 4,16 & 0.69 & & High \\
\hline
\end{tabular}

Results in Table (2) indicate that the degree of secondary school teachers' perception of the importance of applying the Deschooling principles of Ivan Illich in the educational learning process was high reaching the mean of (4.16). Where the first field came in the first place "exchange of experts" with the mean of (4.35). And in the second category, the field of professional educators with an arithmetic mean (4.13). In the third and final 
level, came the fields of "learning materials network" and "peer compatibility" with the mean value of $(4,08)$. This is due to the belief of the study sample that the school is no longer the only source in providing knowledge, raising awareness in the light of the information and technology revolution and the multiplicity of educational methods and how they affect the behavior of individuals and prepare them to participate in life, Which can be a competition for school education, including Deschooling principles of Ivan Illich, which simulates the reality of the learner.

Table 3. Arithmetic means, standard deviations and ranking of the importance of applying the Deschooling principles of Ivan Illich in the educational learning process for the first field (Network educational materials)

\begin{tabular}{|c|c|c|c|c|c|}
\hline No. & Paragraph & $\begin{array}{l}\text { Arithmetic } \\
\text { means }\end{array}$ & $\begin{array}{l}\text { Standard } \\
\text { deviations }\end{array}$ & Rank & Level \\
\hline 1 & $\begin{array}{l}\text { The natural environment is used as a source of } \\
\text { information }\end{array}$ & 4,28 & 0.82 & 1 & High \\
\hline 3 & It prepares students for practical life in society & 4,26 & 0.69 & 2 & High \\
\hline 4 & $\begin{array}{l}\text { Opens the way for dealing with different sources of } \\
\text { information }\end{array}$ & 4,25 & 0.64 & 3 & High \\
\hline 2 & $\begin{array}{l}\text { The learning process is integrated with daily life } \\
\text { problems }\end{array}$ & 4,24 & 0.66 & 4 & High \\
\hline 11 & Helps to create knowledge for the learner & 4,15 & 0.73 & 5 & High \\
\hline 9 & Give importance to Deschooling activities & 4,15 & 0.92 & 5 & High \\
\hline 13 & Make students bold in expressing their ideas & 4,14 & 0.74 & 6 & High \\
\hline 5 & Increase flexibility in the learning process & 4,13 & 0.79 & 7 & High \\
\hline 8 & $\begin{array}{l}\text { Develop a voluntary partnership for parents in the } \\
\text { educational process }\end{array}$ & 4,11 & 0.86 & 8 & High \\
\hline 14 & Reduce the time and effort to access the information & 4,10 & 0.83 & 9 & High \\
\hline 10 & Supports self-learning for students & 4,09 & 0.76 & 10 & High \\
\hline 17 & Promote teamwork among students & 4,06 & 0.91 & 11 & High \\
\hline 12 & Allows each learner to give his opinion equally & 4,05 & 0.76 & 12 & High \\
\hline 15 & Allows the teacher to change the teaching method & 4,01 & 0.94 & 13 & High \\
\hline 7 & Increase access to education for donors & 4,01 & 0.84 & 14 & High \\
\hline 18 & Provide curriculum all day throughout the week & 3,99 & 0.90 & 15 & High \\
\hline 6 & $\begin{array}{l}\text { Increase creativity and innovation in the educational } \\
\text { process }\end{array}$ & 3,95 & 0.90 & 16 & High \\
\hline 16 & $\begin{array}{l}\text { Taking into consideration individual differences } \\
\text { among students }\end{array}$ & 3,90 & 0.88 & 17 & High \\
\hline 9 & $\begin{array}{l}\text { It undermines the educational and instructional role } \\
\text { of the teacher }\end{array}$ & 3,68 & 1.04 & 18 & High \\
\hline Tota & score & \multicolumn{2}{|c|}{4.08} & & High \\
\hline
\end{tabular}

It should be noted from Table (3) that the degree of secondary school teachers' perception for the importance of applying the Deschooling principles of Ivan Illich in the educational learning process for the first field (Network educational materials) was very high with an mean ranging between (4.28- 3.68), the paragraph (1), which states that "the natural environment is used as a source of information" came first with the mean of 4.28 and standard deviation of (0.82). This may be attributed to the fact that the natural environment has a great role in shaping the personality traits of humanity; it is all that surrounds the individual from the influences represented in the family, and it is the first social vessel to form the personality traits of the human being, the source of satisfying his psychological and emotional needs, besides the religious institutions, which are one of the strongest factors affecting the education of individuals and develop their conscience, and the media is the strongest mean of education in the natural environment, as they transcend all physical and moral boundaries. Cultural clubs also have the great impact of educating people on personal skills and abilities through educational roles where people learn patterns of behavior, ideas, habits and values through participation in seminars and lectures and various sports. Social media networks also provide a better learning environment through the exchange of information with others and constructive discussion that stimulate the learner's skills, provide opportunities for learning, increase the ability of individuals to think creatively, and increased their importance in the field of Deschooling education in creating ideas. 
In the second level came paragraph (3), which states that "students prepare for practical life in society", with the mean of 4.26 and the standard deviation of 0.69 , this may be due to the fact that Deschooling modes of education, such as the information exchange networks provide the learner with the skills necessary to deal with modern-day data from mental skills to serve their skills, which qualify them for practical life and entry into the labor market without linking them to a specific curriculum.

Paragraph (4) came in the third level, which states that "the field of dealing with different sources of information" with the mean of 4.25 and standard deviation of 0.64 and with degree, and this is due to that the textbook is no longer the only source to provide learners with skills and knowledge as both mental and emotional skill are the requirements of the era of knowledge which requires the learner to deal with different sources of information, whether electronic books or databases and educational sites.

Paragraph (16), which states "taking into account individual differences between students", came the second last level with the mean of (3.90) and standard deviation (0.88), this may be due to the fact that the learner needs constant guidance in dealing with networks of information as the exchange needs special abilities and needs to prepare individuals to deal with this type of technology.

Paragraph (18), which states: "It undermines the educational and instructional role of the teacher" came last with a mean of (3.68) and a standard deviation of (1.04), this is due to the belief of the sample of the study that the technology will be at the forefront of communicating knowledge to students and the role of the teacher will shift from being the first provider of information to the learner.

Table 4. Arithmetic means, standard deviations and ranking of the importance of applying the Deschooling principles of Ivan Illich in the educational learning process for the second field (Exchange of experts)

\begin{tabular}{|c|c|c|c|c|c|}
\hline No. & Paragraph & $\begin{array}{l}\text { Arithmetic } \\
\text { means }\end{array}$ & $\begin{array}{l}\text { Standard } \\
\text { deviations }\end{array}$ & Rank & Level \\
\hline 4 & Develop an individual's ability to think & 4,19 & 0.79 & 1 & High \\
\hline 6 & $\begin{array}{l}\text { To open the door to the competent authorities such as } \\
\text { research and evaluation centers }\end{array}$ & 4,15 & 0.75 & 2 & High \\
\hline 1 & $\begin{array}{l}\text { Given the opportunity to the experienced and good skill } \\
\text { to teach others }\end{array}$ & 4,14 & 0.73 & 3 & High \\
\hline 5 & $\begin{array}{l}\text { Enhances the capabilities of individuals in different } \\
\text { environments }\end{array}$ & 4,10 & 0.84 & 4 & High \\
\hline 12 & $\begin{array}{l}\text { Coordinates and cooperates with relevant educational } \\
\text { departments }\end{array}$ & 4,01 & 0.76 & 5 & High \\
\hline 7 & $\begin{array}{l}\text { Participation of professional trade unions specialized in } \\
\text { evaluating performance and educational training }\end{array}$ & 3,95 & 0.80 & 6 & High \\
\hline 10 & Rationalization of long-term financing of education & 3,93 & 0.76 & 7 & High \\
\hline 11 & Provides many educational resources & 3,91 & 0.82 & 8 & High \\
\hline 2 & $\begin{array}{l}\text { Give a key role to parents in communicating their } \\
\text { knowledge to others }\end{array}$ & 3,90 & 0.81 & 9 & High \\
\hline 8 & $\begin{array}{l}\text { Transferring abstract information in the curriculum to } \\
\text { tangible experiences of the student }\end{array}$ & 3,90 & 0.89 & 9 & High \\
\hline 9 & $\begin{array}{l}\text { Supports the development of alternative education } \\
\text { systems }\end{array}$ & 3,90 & 0.84 & 9 & High \\
\hline 3 & $\begin{array}{l}\text { The partnership of specialized entities develops pilot } \\
\text { experiences such as the One-Class Schools project }\end{array}$ & 3,79 & 0.86 & 12 & High \\
\hline Total & score & 4.01 & 0.82 & & High \\
\hline
\end{tabular}

Table (4) shows that the degree of secondary school teachers' perception for the importance of applying the Deschooling principles of Ivan Illich in the educational learning process in the field of exchange of experts was very high with the mean of (4.01). The arithmetic means ranged between (4.19-3.79).

Paragraph (4), which states that "Develop an individual's ability to think" came first with the arithmetic mean of $(4,19)$ and the standard deviation of $(0.79)$, and this may be due to the change in the thinking pattern of the mind, to see the individual things in the broader context, and through interaction with others as the individual receives the effects from his surrounding environment and is active while taking a complex analyses through the 
interaction process. At the second level came paragraph (6), which states that "To open the door to the competent authorities such as research and evaluation centers" with the mean of $(4,15)$ and standard deviation of $(0.75)$, this is because education is not the responsibility of one party only, but the responsibility of all institutions of the state, and all parties must be involved. Education is a community process aimed at promoting the individual and unleashing his potential by examining the extent to which the educational process reaches its objectives.

Paragraph (3) came last, which states that "The partnership of specialized entities develops pilot experiences such as the One-Class Schools project", with the mean of 3.79 and the standard deviation of 0.86 .

Table 5. Arithmetic means, standard deviations and ranking of the importance of applying the Deschooling principles of Ivan Illich in the educational learning process for the third field (Peer compatibility)

\begin{tabular}{|c|c|c|c|c|c|}
\hline No. & Paragraph & $\begin{array}{l}\text { Arithmetic } \\
\text { means }\end{array}$ & $\begin{array}{l}\text { Standard } \\
\text { deviations }\end{array}$ & Rank & Level \\
\hline 9 & $\begin{array}{l}\text { Provide students with the opportunity to highlight their } \\
\text { talents and mental abilities }\end{array}$ & 4,28 & 0.54 & 1 & High \\
\hline 1 & Students deal with each other in a suitable way & 4,16 & 0.77 & 2 & High \\
\hline 6 & $\begin{array}{l}\text { Peer training improves teachers' effectiveness in } \\
\text { educating their peers }\end{array}$ & 4,15 & 0.83 & 3 & High \\
\hline 8 & $\begin{array}{l}\text { Peer-friendliness is more confident than learners } \\
\text { themselves }\end{array}$ & 4,15 & 0.68 & 3 & High \\
\hline 3 & $\begin{array}{l}\text { The close social level plays an important role in raising } \\
\text { the level of education }\end{array}$ & 4,11 & 0.62 & 5 & High \\
\hline 7 & $\begin{array}{l}\text { Different cultures among peers introduce a new } \\
\text { dimension to education and culture }\end{array}$ & 4,11 & 0.64 & 5 & High \\
\hline 5 & $\begin{array}{l}\text { Raise similar hopes and aspirations among peers from } \\
\text { the level of access to education }\end{array}$ & 4,10 & 0.75 & 7 & High \\
\hline 10 & Modify some inappropriate behaviors & 4,08 & 0.74 & 8 & High \\
\hline 11 & Developing the skill of constructive criticism of ideas & 4,08 & 0.79 & 8 & High \\
\hline 2 & $\begin{array}{l}\text { Achieving the objectives of the educational process } \\
\text { increases the number of sessions with the interviewer }\end{array}$ & 4,05 & 0.83 & 10 & High \\
\hline 13 & Gain the skill of dialogue among students & 4,02 & 0.90 & 11 & High \\
\hline 12 & $\begin{array}{l}\text { Personal compatibility and tendencies increase the } \\
\text { educational benefit of interacting with peers }\end{array}$ & 4,01 & 0.68 & 12 & High \\
\hline 12 & Increase the chance of solving problems & 4,00 & 0.94 & 13 & High \\
\hline 14 & $\begin{array}{l}\text { Develop the patience, tolerance and respect required in } \\
\text { education }\end{array}$ & 3,96 & 0.81 & 14 & High \\
\hline 15 & Promote social justice standards & 3,94 & 0.84 & 15 & High \\
\hline \multicolumn{2}{|c|}{ Total score } & 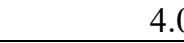 & & & High \\
\hline
\end{tabular}

It should be noted from Table (5) that the degree of secondary school teachers' perception for the importance of applying the Deschooling principles of Ivan Illich in the educational learning process in the field of Peer compatibility was very high with the arithmetic mean of $(4,08)$. The means ranged between $(4.28-3.94)$. Paragraph (9), which states that "the student has the opportunity to demonstrate his talents and mental abilities" came first with the mean of 4.28 and the standard deviation of (0.54), and this may be due to the fact that the exchange of knowledge and experience with the interviewer of the same scientific level with people who share the same interests in research and knowledge allows students to highlight their talents and mental abilities. Paragraph (15) which states that "Promote social justice standards" came last with the mean of (3.94) and the standard deviation of $(0.84)$.

Table 6. Arithmetic means, standard deviations and ranking of the importance of applying the Deschooling principles of Ivan Illich in the educational learning process for the fourth field (Professional Educators)

\begin{tabular}{rlllllll}
\hline No. & Paragraph & & $\begin{array}{l}\text { Arithmetic } \\
\text { means }\end{array}$ & $\begin{array}{l}\text { Standard } \\
\text { deviations }\end{array}$ & Rank & Level \\
\hline 13 & Give educators the ability & to observe & individual & 4,31 & 0.60 & 1 & High \\
\hline
\end{tabular}




\begin{tabular}{|c|c|c|c|c|c|}
\hline & differences among students & & & & \\
\hline 2 & Provides effort and time in teacher performance & 4,27 & 0.65 & 2 & High \\
\hline 3 & Open the way to give ideas to anyone & 4,23 & 0.71 & 3 & High \\
\hline 1 & The role of the teacher is rational leadership & 4,20 & 0.65 & 4 & High \\
\hline 12 & Allowing educators to instill values of moral education & 4,19 & 0.68 & 5 & High \\
\hline 6 & Freedom is left to everyone to learn something & 4,17 & 0.73 & 6 & High \\
\hline 8 & $\begin{array}{l}\text { Educators are required to know the educational } \\
\text { networks }\end{array}$ & 4,13 & 0.68 & 7 & High \\
\hline 4 & $\begin{array}{l}\text { Transforming the role of the teacher from a knowledge } \\
\text { vector into an educational mentor }\end{array}$ & 4,11 & 0.75 & 8 & High \\
\hline 5 & $\begin{array}{l}\text { Provides an opportunity for all those wishing to present } \\
\text { a case to the public to carry out their task }\end{array}$ & 4,11 & 0.57 & 8 & High \\
\hline 9 & Create a special quality of teachers & 4,05 & 0.71 & 10 & High \\
\hline 7 & $\begin{array}{l}\text { Educators define what useful things an individual } \\
\text { should learn }\end{array}$ & 4,04 & 0.86 & 11 & High \\
\hline 11 & Increase the experience of educators & 3,97 & 0.90 & 12 & High \\
\hline 10 & Reduce the monopoly of knowledge & 3,94 & 0.89 & 13 & High \\
\hline \multicolumn{3}{|c|}{ Total score } & & & High \\
\hline
\end{tabular}

It is noted in Table (6) that the degree of secondary school teachers' perception for the importance of applying the Deschooling principles of Ivan Illich in the educational learning process in the field of Professional Educators was very high with the arithmetic mean of (4.13), the arithmetic means ranged Between (4.31 - 3.94). Paragraph 13, which states that "teachers give the ability to observe individual differences between students" came first rank, with the mean of 4.31 and the standard deviation of 0.60 . While paragraph (10) which states that "Reduce the monopoly of knowledge" came last with the arithmetic mean of (3.94) and the standard deviation of $(0.89)$, and this may be due to the fact that the learner is free to use the teachers knowledge if he wants to.

\subsection{Results of the Second Question}

To answer the question, the arithmetic means, standard deviations, and (T) values were calculated. The results were as follows in table (7):

Table 7. The results of T-test for the independent samples in the perception of secondary school teachers of the importance of applying the Deschooling principles of Ivan Illich in the educational learning process upon gender variable

\begin{tabular}{ccccccc}
\hline \multicolumn{2}{c}{ Variable } & Frequency & Arithmetic means & Standard deviations & T value & Level of significance \\
\hline \multirow{2}{*}{ Gender } & Male & 48 & 4.01 & 0.52 & -1.386 & \multirow{2}{*}{0.16} \\
& Female & 52 & 4.13 & 0.29 & & \\
\hline
\end{tabular}

The data in the table (7) show that there are no statistically significant differences at the level of $(\alpha=0.05)$ in the degree of secondary school teachers' perception of the importance of applying the Deschooling principles of Ivan Illich in the educational learning process upon the gender variable. This may be due to the fact that all secondary school teachers are exposed to the same training courses that have become willing to work to make the change in the school environment to meet the requirements of the modern age, and to meet the new needs of the educational process and to enable students to possess the knowledge keys, exploit that knowledge in the production of new knowledge. This result was agreed upon with the study of AlZboun \& Ababneh (2010), which turned the role of the teacher into a facilitator of the process of education and changing the role of the student from the recipient of knowledge to the participant in the acquisition, and the teaching process will become more interesting and effective using ICTs. 
Table 8. The results one way ANOVA teas in the perception of secondary school teachers of the importance of applying the Deschooling principles of Ivan Illich in the educational learning process upon qualification variable

\begin{tabular}{lllllll}
\hline Variable & Source of variance & $\begin{array}{l}\text { Total } \\
\text { squares }\end{array}$ & $\begin{array}{l}\text { Degree } \\
\text { freedom }\end{array}$ & $\begin{array}{l}\text { Mean } \\
\text { squares }\end{array}$ & $\begin{array}{l}(\mathrm{P}) \\
\text { value }\end{array}$ & $\begin{array}{l}\text { Level } \\
\text { significance }\end{array}$ \\
\hline \multirow{3}{*}{ Qualification } & Between groups & 1.001 & 2 & 0.501 & 2.97 & 0.056 \\
& Within groups & 16.180 & 98 & 0.169 & & \\
& Total & 17.181 & 100 & & & \\
\hline
\end{tabular}

The data in the table (8) show that there are no statistically significant differences at the level of $(\alpha=0.05)$ in the degree of secondary school teachers' perception of the importance of applying the Deschooling principles of Ivan Illich in the educational learning process upon the qualification variable.

This result means the acceptance of the null hypothesis related to the variables of qualification and gender, there is no significant difference between the levels of educational qualification and gender at the level of $(\alpha=0.05)$ in the degree of secondary school teachers' perception of the importance of applying the Deschooling principles of Ivan Illich in the educational learning process.

\section{Recommendations}

After reviewing the results of the study, it is necessary to alert the educational authorities to the need of an integrated education mixture, which combines direct learning in the school and directly outside the school walls, for that the researcher suggested the following recommendations:

1. Re-examine the objectives of education in the light of a renewed vision for sustainable human and social development that is equitable and can be applied together, and in this vision we should take into account the social, environmental and economic dimensions of the comprehensive development processes and linking them to education processes.

2. The need to build an integrated approach based on the return to the interpretation and protection of the four pillars of education which are: learning to learn, learn to work, learn to be and learn to live.

3. To undertake further research on Deschooling education, which deals with different dimensions.

\section{References}

Abu Fakhr, Z. (2012). The effect of virtual learning in the collection of the methods of teaching sociology among the students of the diploma of educational qualification at the Syrian Virtual University. Journal of the Union of Arab Universities for Education and Psychology, 10(3), 40-70.

Al-Shaikh, N. B. I. (2007). Saudi Youth Attitudes towards the Impact of the Culture of Globalization on Local Values: An Empirical Study of a Sample of Students of Some Saudi Universities, unpublished Dissertation, King Saud University, Riyadh, Saudi Arabia.

Mohammed, A. T. (2015). The Future of Deschooling in the Society. Educational and Psychological Sciences, $8(4), 1181-1239$.

Mohammed, A., \& Ababneh, S. (2010). Future Scenarios for the Use of ICTs in the Development of the Educational System. Al-Najah University for Research (Humanities), 24(3), 826-799.

Bauto, L. M. (2016). Socio-Cultural Values as Community Local Wisdom Katoba Muna in The Development of Learning Materials Social Studies and History. Historia: Jurnal Pendidikan Sejarah dan Sejarah, 14(2), 195-218.

Clara, M., \& Barbera, E. (2014). Three Problems with the connectives, 30(3), 197-206.

Illich, I. (1971). Alternatives to Schooling. Times (London) Educational Supplement, 2945, 18-47.

Mustafa, Amira (2016). A suggested guide for the educational supervising role of the director of the secondary school in the Directorate of Education of the Marka Brigade based on the functions of modern educational supervision, unpublished master thesis, University of Jordan, Amman, Jordan.

Nasser, I., \& Mohammed, A. (2015). Contemporary Educational Thought, Dar Wael Publishing and Distribution: Amman, Jordan.

Putnam, R. T., \& Borko, H. (2000). What do new views of knowledge and thinking have to say about research on teacher learning? Educational Researcher, 29(1), 4-15.

Reimer, E. (1971). School is dead. Harmondsworth, Middlesex, England: Penguin books. 
Shaidullina, A. R., Pavlova, N. A., Minsabirova, V. N., Burdukovskaya, E. A., Yunusova, A. B., Letyaev, V. A., \& Afanasev, A. S. (2015). Integration processes in education: Classification of integration types. Review of European Studies, 7(4), 27.

Todd, J. (2012). From deschooling to unschooling: Rethinking anarchopedagogy after Ivan Illich. Anarchist Pedagogies, 69-87.

Vijaya, K., \& Ravi, E. (2015). A study on assessment of Non-Scholastic Abilities in Primary School Children. International Journal of Scientific Research and Management (IJSRM), 3(5), 2797-2806.

\section{Copyrights}

Copyright for this article is retained by the author(s), with first publication rights granted to the journal.

This is an open-access article distributed under the terms and conditions of the Creative Commons Attribution license (http://creativecommons.org/licenses/by/4.0/). 